ISSN 0258-7122

Bangladesh J. Agril. Res. 37(3): 515-527, September 2012

\title{
TRACE ELEMENTS CONTENT IN VEGETABLES GROWN IN INDUSTRIALLY POLLUTED AND NON-POLLUTED AREAS
}

\author{
HABIB MOHAMMAD NASER ${ }^{1}$, NASHIR UDDIN MAHMUD ${ }^{2}$ \\ SARMIN SULTANA ${ }^{3}$, REBECA GOMES ${ }^{4}$, MUKHLESUR RAHMAN ${ }^{5}$
}

\begin{abstract}
Field survey based laboratory studies were carried out to investigate trace elements contents in soils and vegetables collected from industrially polluted and non-polluted areas. The content of four trace elements, such as manganese $(\mathrm{Mn})$, iron $(\mathrm{Fe})$, copper $(\mathrm{Cu})$, and zinc $(\mathrm{Zn})$ in four popular vegetables, namely spinach (Spinacia oleracea), red amaranth (Amaranthus tricolor), bottle gourd (Lagenaria vulgaris), and pumpkin (Cucurbita moschata) and the rizosphere soils of the respective crops were collected from three locations viz. i) directly polluted (Kaliakoir, Konabari, Gazipur), ii) indirectly polluted (Zorun, Konabari, Gazipur), and iii) non-polluted (BARI, Gazipur) areas. In all four vegetables, a similar trend in metal contents was observed i.e. directly polluted $>$ indirectly polluted $>$ non-polluted. The Mn and Fe concentrations were found in the order of spinach>red amaranth $>$ bottle gourd>pumpkin, whereas it was little bit irregular pattern for $\mathrm{Zn}$. The $\mathrm{Cu}$ concentration was higher in spinach followed by red amaranth and the least in bottle gourd irrespective of the location. Mean concentration of $\mathrm{Mn}, \mathrm{Fe}$, and $\mathrm{Cu}$ in vegetables from investigated areas were below the recommended level except $\mathrm{Zn}$. However, the higher concentrations of $\mathrm{Mn}, \mathrm{Fe}, \mathrm{Cu}$, and $\mathrm{Zn}$ in the polluted (either directly or indirectly) area indicates that industrial activities, such as discharge their wastes and effluents into the natural ecosystems in most cases without any treatment, thus causing health hazard as well as environmental pollution, especially with heavy metals and organic toxic.
\end{abstract}

Keywords: soil, vegetables, trace elements, concentration, pollution.

\section{Introduction}

Heavy metal pollution in air-water-soil-plant systems is of major environmental concern throughout the world including Bangladesh. Bangladesh has at present about 30000 large and small industrial units. Most of these industries discharge its wastes and effluents into the natural ecosystems in most cases without any treatment, thus causing environmental pollution, especially with heavy metals and organic toxic. These hazardous wastes and effluents are generally discharged in low-lying areas, along road side, or in the vicinity of the industrial installations

\footnotetext{
${ }^{1}$ Senior Scientific Officer, Soil Science Division, Bangladesh Agricultural Research Institute (BARI), Gazipur-1701, ${ }^{2 \& 3}$ Scientific Officer, Soil Science Division, BARI, Gazipur-1701, ${ }^{4}$ Principal Scientific Officer, Soil Science Division, BARI, Gazipur-1701, ${ }^{5}$ Director, Training \& Communication, BARI, Gazipur-1701, Bangladesh.
} 
(Chamon et al., 2011). The important heavy metals discharged from industries in Bangladesh are cadmium $(\mathrm{Cd})$, lead $(\mathrm{Pb})$, chromium $(\mathrm{Cr})$, mercury $(\mathrm{Hg})$, zinc $(\mathrm{Zn})$, arsenic (As) and in few cases copper (Cu) and manganese (Mn) (Nuruzzaman et al., 1995). Long-term use of industrial or municipal wastewater in irrigation is known to have significant contribution to trace elements, such as $\mathrm{Cr}, \mathrm{Mn}, \mathrm{Ni}, \mathrm{Cu}, \mathrm{Zn}, \mathrm{Pb}$, and Cd in surface soil (Mapanda et al., 2005). Excessive accumulation of trace elements in agricultural soils through wastewater irrigation may not only result in soil contamination but also affect food quality and safety (Muchuweti et al., 2006; Sharma et al., 2007).

Cultivated land in the vicinity of industrial areas, which is irrigated by river water, gets contaminated because the industrial effluents enter into river. Additionally, little or no treatment is applied to the industrial discharges to detoxify the wastewater draining into rivers. The problem of water pollution due to toxic metals has begun to cause concern now in most metropolitan cities. The toxic heavy metals entering the ecosystem may lead to geoaccumulation, bioaccumulation and biomagnifications (Prabu, 2009). Heavy metals like Fe, $\mathrm{Cu}$, $\mathrm{Zn}, \mathrm{Mn}$ and other trace elements are important for proper functioning of biological systems and their deficiency or excess could lead to a number of disorders (Ward, 1995).

Environmental pollution is now-a-days a cause of concern. Heavy metal pollution of agricultural soil and vegetables is one of the most severe ecological problems on a world scale and also in Bangladesh. The food chain contamination is the major pathway of heavy metal exposure for humans (Khan et al., 2008). Some trace elements are essential in plant nutrition, but plants growing in the nearby zone of industrial areas display increased concentration of heavy metals serving in many cases as biomonitors of pollution loads (Mingorance et al., 2007). Vegetables cultivated in soils polluted with toxic metals due to industrial activities take up heavy metals and accumulate them in their edible and nonedible parts in quantities high enough to cause clinical problems both to animals and human beings consuming these metal-rich plants because there is no good mechanism for their elimination from the human body (Arora et al., 2008; Alam et al., 2003). Therefore, a better understanding of heavy metal sources, their accumulation in the soil and the effect of their presence in water, soil and on plant systems seem to be particularly important issues of present day research on risk assessment. Information regarding the accumulation of essential heavy metals in vegetables in industrially polluted areas in Bangladesh is scarce. Thus the research work has been undertaken i) to highlight the accumulation status of essential heavy metals in vegetables; and ii) to compare the essential heavy metal status of vegetables and soils in polluted and non-polluted areas. 


\section{Materials and Method}

\section{Selection of sampling sites and vegetables}

Samples of soils and vegetables were taken from three agricultural areas exposed to different degrees of environmental pollution. Area 1: Direct pollution due to irrigation by contaminated river water (Kaliakoir, Konabari, Gazipur). The vegetable samples in this area were taken from the side irrigated with the Turag river water. The river Turag is highly polluted by industrial effluents, contaminated with sewage sludge, municipal waste water, and urban pollution. Area 2: Indirect pollution by contaminated water of pond and canal (Zorun, Konabari, Gazipur), which is highly polluted by industrial effluents, sewage sludge, municipal waste water, and urban pollution. During rainy season, pond and canals are overflowed by rain water and submerged the adjacent cultivable land where the farmers grew their vegetables in winter. Area 3: The same vegetables samples were collected from Bangladesh Agricultural Research Institute (BARI), Joydebpur, Gazipur, experimental field near the net house of Soil Science Division, considered as check area. Two leafy vegetables spinach (Spinacia oleracea) and red amaranth (Amaranthus tricolor), and two fruity vegetables bottle gourd (Lagenaria vulgaris), and pumpkin (Cucurbita moschata), grown extensively in these sites were selected for this study. Soil samples and samples of vegetables grown in these soils were taken from four different places in each location. The plant samples represent whole parts of the plant of respective vegetable (fruits, leaves, stems, and roots-wherever suitable; i.e., fruits for bottle gourd and pumpkin). Soil samples from rhizosphere of respective vegetable $(0-15 \mathrm{~cm})$ were collected with a stainless steel auger from the same locations simultaneously with the vegetables. Samples of soils and vegetables were taken by a random process.

\section{Preparation and preservation}

The vegetables were washed in fresh running water to eliminate dust, dirt, possible parasites or their eggs and then were again washed with deionized water. The clean vegetable samples were cut into 2 -cm pieces and air-dried and placed in an electric oven at $65^{\circ} \mathrm{C}$ for $72-96 \mathrm{~h}$ depending on the sample size. The dried vegetables samples were homogenized by grinding using a ceramic coated grinder and used for metal analysis. All soil samples were spread on plastic trays and allowed to dry at ambient temperature for 8 days. The dried samples of soils were ground with a ceramic coated grinder and sieved through a 2-mm nylon sieve. The final samples were kept in labeled polypropylene containers at ambient temperature before analysis. 


\section{Digestion and determination}

One gram of dry matter was weighed into $50-\mathrm{ml}$ beakers, followed by the addition of $10 \mathrm{ml}$ mixture of analytical grade acids $\mathrm{HNO}_{3}: \mathrm{HCIO}_{4}$ in the ratio 5:1. The digestion was performed at a temperature of about $190^{\circ} \mathrm{C}$ for $1.5 \mathrm{~h}$. After cooling, the solution was made up to a final volume $(30 \mathrm{ml})$ with distilled water in a volumetric flask. For soil, same procedure was done as stated above. The metal concentrations were determined by atomic absorption spectrometry using a VARIAN model AA2407 Atomic Absorption Spectrophotometer (AAS). Analysis of each sample was carried out three times to obtain representative results. The mean data reported in $\mu \mathrm{g} / \mathrm{g}$ (on a dry matter basis). Statistical analyses were performed by Tukey's multiple comparisons test by using Excel Statistics version 4.0 (Esumi Co. Ltd., Tokyo, Japan).

\section{Results and Discussion}

The mean concentrations of $\mathrm{Mn}, \mathrm{Fe}, \mathrm{Cu}$, and $\mathrm{Zn}$ in vegetables and soils studied are given in Table $1 \& 2$. The magnitude of trace elements content in vegetables and soils in respect of three locations was directly polluted>indirectly polluted $>$ non-polluted. Several studies have indicated that vegetables grown in heavy metals contaminated soils have higher concentrations of heavy metals than those grown in uncontaminated soils (Guttormsen et al., 1995; Dowdy and Larson, 1995). The concentrations of trace elements ( $\mu \mathrm{g} / \mathrm{g}$ of dry wt.) in vegetables were quite variable such as $\mathrm{Mn}$ (15.5-52.8), Fe (57.2-361), Cu (8.0118.3) and Zn (27.8-84.4).

A statistically significant difference $(\mathrm{P}<0.01)$ was found between the polluted (either directly or indirectly) and non-polluted areas in both vegetables and soils. There were significant differences in the average $\mathrm{Mn}, \mathrm{Fe}, \mathrm{Cu}$, and $\mathrm{Zn}$ concentrations ( $\mu \mathrm{g} / \mathrm{g}$ of dry wt) in different vegetable species (spinach, red amaranth, bottle gourd, and pumpkin) in different locations. In directly polluted area, $\mathrm{Mn}(\mu \mathrm{g} / \mathrm{g}$ of dry wt) was highest in spinach with a mean of 52.8 followed by red amaranth with a mean of 48.2 and minimum in bottle gourd i.e. 25.6. Iron ( $\mu \mathrm{g} / \mathrm{g}$ of dry wt) was highest in spinach with a range of 186 to 361 followed by red amaranth with a range of 195 to 328 and pumpkin having lowest 68.9 to 102 i.e. spinach $>$ red amaranth>bottle gourd $>$ pumpkin. Copper $(\mu \mathrm{g} / \mathrm{g}$ of dry wt) was found highest in spinach with a range of 12.0 to 18.3 followed by red amaranth with a range of 9.86 to 14.1 and pumpkin was 9.14 to 12.6. Lowest content was found in bottle gourd (8.01-10.9). The extent of $\mathrm{Cu}$ content can be regarded in the order of spinach $>$ red amaranth $>$ pumpkin $>$ bottle gourd. Zinc concentrations ( $\mu \mathrm{g} / \mathrm{g}$ of dry wt) followed the trend spinach>bottle gourd $>$ pumpkin $>$ red amaranth. 
Table 1. Mean Fe, Mn, and Zn concentration ( \pm , standard deviation) of vegetables from directly polluted, indirectly polluted and non-polluted areas.

\begin{tabular}{|c|c|c|c|c|c|c|c|c|}
\hline \multirow{3}{*}{ Location } & \multicolumn{8}{|c|}{ Leafy vegetables $(\mu \mathrm{g} / \mathrm{g})$} \\
\hline & \multicolumn{4}{|c|}{ Spinach } & \multicolumn{4}{|c|}{ Red amaranth } \\
\hline & Mn & $\mathbf{F e}$ & $\mathrm{Cu}$ & Zn & Mn & $\mathbf{F e}$ & $\mathrm{Cu}$ & Zn \\
\hline $\begin{array}{l}\text { Directly } \\
\text { polluted }\end{array}$ & $52.8 \pm 1.92 b$ & 361士13.0c & $18.3 \pm 2.10 \mathrm{~b}$ & $84.4 \pm 3.71 c$ & $48.2 \pm 4.56 b$ & $328 \pm 14.8 \mathrm{~b}$ & $14.1 \pm 2.25 b$ & $39.1 \pm 3.34 b$ \\
\hline $\begin{array}{c}\text { Indirectly } \\
\text { polluted }\end{array}$ & $52.7 \pm 3.24 b$ & $251 \pm 2.49 b$ & $14.5 \pm 1.27 \mathrm{ab}$ & $48.6 \pm 4.46 b$ & $35.8 \pm 2.07 a$ & $204 \pm 7.81 b$ & $13.4 \pm 1.48 b$ & $37.2 \pm 2.80 \mathrm{ab}$ \\
\hline $\begin{array}{c}\text { Non- } \\
\text { polluted }\end{array}$ & $36.5 \pm 1.65 a$ & $186 \pm 4.09 \mathrm{a}$ & $12.0 \pm 1.19 \mathrm{a}$ & $35.2 \pm 2.65 a$ & $31.1 \pm 2.80 \mathrm{a}$ & $195 \pm 10.9 \mathrm{a}$ & $9.86 \pm 1.04 \mathrm{a}$ & $31.0 \pm 2.19 \mathrm{a}$ \\
\hline \multirow{3}{*}{ Location } & \multicolumn{8}{|c|}{ Fruity vegetables $(\mu \mathrm{g} / \mathrm{g})$} \\
\hline & \multicolumn{4}{|c|}{ Bottle gourd } & \multicolumn{4}{|c|}{ Pumpkin } \\
\hline & Mn & $\mathbf{F e}$ & $\mathrm{Cu}$ & Zn & Mn & $\mathbf{F e}$ & $\mathrm{Cu}$ & Zn \\
\hline $\begin{array}{l}\text { Directly } \\
\text { polluted }\end{array}$ & $25.6 \pm 2.64 b$ & $153 \pm 9.44 c$ & $10.9 \pm 2.03 b$ & $51.8 \pm 2.14 \mathrm{c}$ & $26.4 \pm 2.90 \mathrm{~b}$ & $102 \pm 6.24 b$ & $12.6 \pm 0.82 b$ & $44.3 \pm 1.75 b$ \\
\hline $\begin{array}{c}\text { Indirectly } \\
\text { polluted }\end{array}$ & $24.1 \pm 1.83 b$ & $75.8 \pm 5.51 b$ & $11.0 \pm 0.49 b$ & $36.2 \pm 2.04 \mathrm{~b}$ & $23.9 \pm 1.22 b$ & $85.8 \pm 12.8 \mathrm{ab}$ & $9.59 \pm 1.43 \mathrm{a}$ & $35.1 \pm 4.07 \mathrm{ab}$ \\
\hline $\begin{array}{c}\text { Non- } \\
\text { polluted }\end{array}$ & $16.5 \pm 1.43 a$ & $57.2 \pm 5.43 a$ & $8.01 \pm 0.50 \mathrm{a}$ & $27.8 \pm 1.15 a$ & $15.4 \pm 1.25 a$ & $68.9 \pm 7.13 a$ & $9.14 \pm 0.89 a$ & $29.6 \pm 1.94 a$ \\
\hline
\end{tabular}

Values in a column followed by a common letter are not significantly different at $\mathrm{P}<0.01$ 
Table 2. Mean Fe, Mn, and Zn concentration ( \pm , standard deviation) of soils from directly polluted, indirectly polluted and non- $\quad \mathcal{O}$ polluted areas.

\begin{tabular}{|c|c|c|c|c|c|c|c|c|}
\hline \multirow{3}{*}{ Location } & \multicolumn{8}{|c|}{ Rhizospheric soils of leafy vegetables $(\mu \mathrm{g} / \mathrm{g})$} \\
\hline & \multicolumn{4}{|c|}{ Spinach } & \multicolumn{4}{|c|}{ Red amaranth } \\
\hline & Mn & $\mathbf{F e}$ & $\mathbf{C u}$ & Zn & Mn & $\mathbf{F e}$ & $\mathbf{C u}$ & Zn \\
\hline $\begin{array}{l}\text { Directly } \\
\text { polluted }\end{array}$ & $297 \pm 6.12 b$ & $1628 \pm 20.8 \mathrm{c}$ & $59.5 \pm 5.26 \mathrm{c}$ & $124 \pm 2.75 b$ & $273 \pm 16.8 b$ & $1561 \pm 28.7 \mathrm{c}$ & $57.2 \pm 3.19 b$ & $95.1 \pm 4.24 b$ \\
\hline $\begin{array}{c}\text { Indirectly } \\
\text { polluted }\end{array}$ & $278 \pm 9.50 b$ & $1447 \pm 14.5 b$ & $41.0 \pm 4.26 \mathrm{~b}$ & $83.0 \pm 8.44 a$ & $259 \pm 16.9 b$ & 1399+38.3b & $53.3 \pm 3.53 b$ & $81.6 \pm 10.8 a b$ \\
\hline $\begin{array}{c}\text { Non- } \\
\text { polluted }\end{array}$ & $170 \pm 16.1 \mathrm{a}$ & $1256 \pm 71.1 \mathrm{a}$ & $26.8 \pm 6.24 a$ & $75.8 \pm 15.4 \mathrm{a}$ & $173 \pm 19.4 a$ & $1281 \pm 8.92 \mathrm{a}$ & $28.6 \pm 5.79 a$ & $72.4 \pm 4.83 a$ \\
\hline
\end{tabular}

\begin{tabular}{|c|c|c|c|c|c|c|c|c|}
\hline \multirow{3}{*}{ Location } & \multicolumn{8}{|c|}{ Rhizospheric soils of fruity vegetables $(\mu \mathrm{g} / \mathrm{g})$} \\
\hline & \multicolumn{4}{|c|}{ Bottle gourd } & \multicolumn{4}{|c|}{ Pumpkin } \\
\hline & Mn & $\mathbf{F e}$ & $\mathrm{Cu}$ & Zn & Mn & $\mathbf{F e}$ & $\mathbf{C u}$ & Zn \\
\hline $\begin{array}{l}\text { Directly } \\
\text { polluted }\end{array}$ & $343 \pm 12.3 c$ & $1602 \pm 64.8 b$ & $44.8 \pm 3.52 b$ & $113 \pm 8.74 b$ & $306 \pm 47.1 b$ & 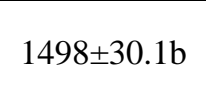 & 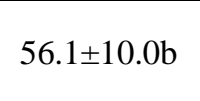 & $108 \pm 13.8 b$ \\
\hline $\begin{array}{c}\text { Indirectly } \\
\text { polluted }\end{array}$ & $303 \pm 18.1 b$ & $1480 \pm 34.5 b$ & $33.0 \pm 4.63 \mathrm{a}$ & $105 \pm 5.77 b$ & $263 \pm 15.9 a b$ & $1395 \pm 32.6 \mathrm{ab}$ & $40.3 \pm 3.38 \mathrm{ab}$ & $84.2 \pm 9.72 \mathrm{ab}$ \\
\hline $\begin{array}{c}\text { Non- } \\
\text { polluted }\end{array}$ & $211 \pm 10.0 \mathrm{a}$ & $1263 \pm 58.1 \mathrm{a}$ & $27.3 \pm 2.99 a$ & $72.7 \pm 10.2 \mathrm{a}$ & $187 \pm 18.2 \mathrm{a}$ & $1295 \pm 55.2 \mathrm{a}$ & $26.5 \pm 6.48 \mathrm{a}$ & $67.0 \pm 6.39 a$ \\
\hline
\end{tabular}


Concentrations of Mn (Table 1) in vegetables in this study were lower than those from Prabu (2009). The mean concentration of $\mathrm{Mn}$ in vegetables from the polluted (either directly or indirectly) area was very similar to the vegetables from Luchnow, India (18.0-57.8 $\mu \mathrm{g} / \mathrm{g}$ of dry wt) (Farooq et al., 1999). Vegetables from the polluted area showed higher levels of Fe than those from the non-polluted area. In fact, significant differences $(\mathrm{P}<0.01)$ were found in the level of Fe in all tested vegetables between polluted and non-polluted areas. The present study revealed that the mean Fe level measured in vegetables from directly polluted area in this study was lower than the concentrations of vegetables reported by Hussain et al. (2006) and Bigdeli \& Selsepour (2008). Mean Fe concentrations varied from 57.2 to $361 \mu \mathrm{g} / \mathrm{g}$ dry wt which was in good agreement with concentrations (111-378 $\mu \mathrm{g} / \mathrm{g}$ dry wt) observed in vegetables by Arora et al. (2008). The concentrations of Fe in vegetables from polluted areas were also found very similar to the values (146.29-350.28 $\mu \mathrm{g} / \mathrm{g}$ dry wt) reported by Ahmed and Goni (2009) for vegetables from effluents-contaminated agricultural land located beside Dhaka Export Processing Zone in Bangladesh. The $\mathrm{Cu}$ levels measured in vegetables in this study were higher than the reported values of Arora et al. (2008) and lower than the reported values of Hussain et al., (2006) and Bigdeli \& Selsepour (2008). However, it was within the range of $\mathrm{Cu}$ concentration (9.81-20.67 $\mu \mathrm{g} / \mathrm{g}$ dry wt.) in vegetables reported by Ahmed and Goni (2009). The concentration of $\mathrm{Zn}$ in this study was within the range of $\mathrm{Zn}$ concentration (14.1-97.7 $\mu \mathrm{g} / \mathrm{g}$ dry wt) in vegetables reported by Hussain et al., (2006) and was very similar to the vegetables from Beijing, China (32.01-69.26 $\mu \mathrm{g} / \mathrm{g}$ dry wt.) (Liu et al., 2005). But the concentration of Zn (27.8-84.4 $\mu \mathrm{g} / \mathrm{g}$ dry $\mathrm{wt})$ in this study was higher than the reported values (19.54-42.06 $\mu \mathrm{g} / \mathrm{g}$ dry wt) of Ahmed and Goni (2009).

Manganese, $\mathrm{Fe}, \mathrm{Cu}, \mathrm{Zn}$ concentrations in soil sampled followed a trend similar to heavy metal concentrations in vegetables (Table 2). The concentration of essential heavy metals ( $\mu \mathrm{g} / \mathrm{g}$ of dry wt) in soils of the study areas ranged from 170 to 343 for Mn, 1256 to 1628 for Fe, 26.5 to $59.5 \mathrm{for} \mathrm{Cu}$, and 67.0 to 124 for $\mathrm{Zn}$. Besides Fe, the mean highest concentration recorded in soils was for $\mathrm{Mn}$ followed by $\mathrm{Zn}$ and $\mathrm{Cu}$. The result of the present study revealed that the level of $\mathrm{Cu}$ and $\mathrm{Zn}$ concentrations in soil was lower than those reported in Tongi, Gazipur, Bangladesh by Chamon et al. (2011) but higher than the result observed in Dhaka Export Processing Zone in Bangladesh (Ahmed and Goni, 2009). Manganese concentration in soil was also higher than the previous result obtained by Mico et al. (2006) and Chamon et al. (2011). Iron concentration was lower than the reported values of Ahmed and Goni (2009) but more than those obtain by Mico et al. (2006).

Manganese, $\mathrm{Fe}, \mathrm{Cu}$, and $\mathrm{Zn}$ concentrations in all vegetables were found to be less than the maximum limits for vegetables (Mn-500, Fe-425.5, Cu-73.3, and 
Zn-99.4) as set by the Codex Alimentarius Commission (FAO/WHO, 2001). The level of $\mathrm{Cu}$, and $\mathrm{Zn}$ concentrations in this study were lower than the permissible levels (Cu-30 and Zn-50) recommended by India (Awashthi, 2000) and in China (Cu-20 and Zn-100) (SEPA, 2005), except, Zn concentration in spinach, which was higher than the permissible levels recommended by India (Awashthi, 2000).

None of the polluted areas soils in this study exceeded the maximum permissible concentration levels for $\mathrm{Cu}(30-300 \mu \mathrm{g} / \mathrm{g})$ and $\mathrm{Zn}(100-600 \mu \mathrm{g} / \mathrm{g})$ reported by different authors like Kabata-Pendias and Pendias (1992), Awashthi (2000) and NEPA, 1995. Iron concentrations in polluted soils were found to be higher than the maximum limits $(1,000 \mu \mathrm{g} / \mathrm{g})$ for Fe in soil reported by KabataPendias and Pendias (1992). The comparison of the mean concentration of $\mathrm{Mn}$ with the permissible level $(2000 \mu \mathrm{g} / \mathrm{g})$ (Allaway, 1990; Kabata-Pendias and Pendias, 1992) shows that the concentration is in the permissible limit.

Correlations between different heavy metals vary widely (Table 3). The result shows positive correlation between total metal content in soils and vegetables. The higher correlation between soil-plant found corresponds to $\mathrm{Cu}$ in spinach. On the other hand, comparatively low correlation between soil-plant was found which corresponds to $\mathrm{Zn}$ in bottle gourd. In respect of vegetable type, leafy vegetables show the higher significant positive correlation than fruity vegetables. However, the degree of relationship between soil and plant in respect of three locations was directly polluted $>$ indirectly polluted $>$ non-polluted.

Bio-concentration factor (BCF) or transfer factor (TF) is a parameter used to describe the transfer of trace elements from soil to plant body (Table 4). It is calculated as the ratio between the concentration of heavy metals in the vegetables and that in the corresponding soil (all based on dry weight) for each vegetable separately (Liu et al., 2006). The BCF or TF is one of the key components of human exposure to metals through the food chain (Prabu, 2009). Table 4 shows the TF for essential heavy metals from soils to vegetables and all $\mathrm{TF}$ are below 1 . The BCF or TF value ranges were Mn $0.075-0.216$, Fe 0.045 -0.222 , $\mathrm{Cu} 0.228-0.465$ and $\mathrm{Zn} 0.345-0.681$. Irrespective of locations, the $\mathrm{TF}$ value for $\mathrm{Mn}, \mathrm{Fe}, \mathrm{Cu}$, and $\mathrm{Zn}$ of spinach was the highest among the all considered vegetables. The degree of TF showed irregular pattern in polluted and non-polluted areas, however, their values in all vegetables were different. The trends of TF for essential heavy metals in different vegetables studied were in the order $\mathrm{Zn}>\mathrm{Cu}>\mathrm{Fe}>\mathrm{Mn}$. Similar result was observed by Prabu (2009) and Kashif et al. (2009). TF value of $\mathrm{Zn}$ was higher among the all considered metals because this metal is more mobile in nature (Kashif et al., 2009). The $\mathrm{TF}$ value of $\mathrm{Zn}$ and Fe in the present study was higher than the TF value of $\mathrm{Zn}$ and Fe observed in Dhaka Export Processing Zone in Bangladesh (Ahmed and Goni, 2009). 
Table 3. Correlations between essential heavy metal content ${ }^{\S}$ in soils and in vegetables $\left(\S=\mu g^{-1}\right.$ of dry wt., $*=p<0.05, * *=p<$ 0.01, ns=non significant).

\begin{tabular}{|c|c|c|c|c|c|c|c|c|}
\hline \multirow{3}{*}{ Location } & \multicolumn{8}{|c|}{ Leafy vegetables } \\
\hline & \multicolumn{4}{|c|}{ Spinach } & \multicolumn{4}{|c|}{ Red amaranth } \\
\hline & Mn & $\mathbf{F e}$ & $\mathbf{C u}$ & Zn & Mn & $\mathbf{F e}$ & $\mathbf{C u}$ & $\mathbf{Z n}$ \\
\hline $\begin{array}{l}\text { Directly } \\
\text { polluted }\end{array}$ & $0.9607 *$ & $0.8503 \mathrm{~ns}$ & $0.9997 * *$ & $0.9615^{*}$ & $0.9932^{* *}$ & $0.9909 * *$ & $0.8066 \mathrm{~ns}$ & 0.9999** \\
\hline $\begin{array}{l}\text { Indirectly } \\
\text { polluted }\end{array}$ & 0.9898* & $0.8543 \mathrm{~ns}$ & $0.9999 * *$ & $0.9613^{*}$ & $0.9973 * *$ & $0.9815^{*}$ & $0.9258 \mathrm{~ns}$ & $0.9999 * *$ \\
\hline $\begin{array}{c}\text { Non- } \\
\text { polluted }\end{array}$ & 0.9688* & $0.8932 \mathrm{~ns}$ & $0.9936 * *$ & $0.9011 \mathrm{~ns}$ & $0.8463 \mathrm{~ns}$ & $0.9823 *$ & $0.8079 \mathrm{~ns}$ & $0.8946 \mathrm{~ns}$ \\
\hline \multirow{3}{*}{ Location } & \multicolumn{8}{|c|}{ Fruity vegetables } \\
\hline & \multicolumn{4}{|c|}{ Bottle gourd } & \multicolumn{4}{|c|}{ Pumpkin } \\
\hline & Mn & $\mathbf{F e}$ & $\mathbf{C u}$ & Zn & Mn & $\mathbf{F e}$ & $\mathbf{C u}$ & Zn \\
\hline $\begin{array}{l}\text { Directly } \\
\text { polluted }\end{array}$ & $0.9980 * *$ & $0.9998 * *$ & 0.9160ns & $0.9444 \mathrm{~ns}$ & $0.8960 \mathrm{~ns}$ & $0.9876 *$ & $0.7417 n s$ & $0.7172 \mathrm{~ns}$ \\
\hline $\begin{array}{l}\text { Indirectly } \\
\text { polluted }\end{array}$ & $0.7336 n s$ & $0.8994 \mathrm{~ns}$ & $0.6698 \mathrm{~ns}$ & $0.8687 \mathrm{~ns}$ & $0.9783 *$ & $0.9267 \mathrm{~ns}$ & $0.9909 * *$ & $0.9987 * *$ \\
\hline $\begin{array}{c}\text { Non- } \\
\text { polluted }\end{array}$ & $0.9929 * *$ & $0.9960 * *$ & $0.9766 *$ & $0.8161 \mathrm{~ns}$ & $0.7275 n s$ & $0.9344 \mathrm{~ns}$ & $0.7297 \mathrm{~ns}$ & $0.9872 *$ \\
\hline
\end{tabular}


Table 4. Transfer factor ( \pm , standard deviation) of $\mathrm{Mn}, \mathrm{Fe}, \mathrm{Cu}$ and $\mathrm{Zn}$ for the soils to vegetables species.

\begin{tabular}{|c|c|c|c|c|c|c|c|c|}
\hline \multirow{3}{*}{ Location } & \multicolumn{8}{|c|}{ Leafy vegetables } \\
\hline & \multicolumn{4}{|c|}{ Spinach } & \multicolumn{4}{|c|}{ Red amaranth } \\
\hline & Mn & $\mathrm{Fe}$ & $\mathbf{C u}$ & $\mathbf{Z n}$ & Mn & $\mathrm{Fe}$ & $\mathbf{C u}$ & $\mathbf{Z n}$ \\
\hline $\begin{array}{l}\text { Directly } \\
\text { polluted }\end{array}$ & $0.178 \pm 0.010$ & $0.222 \pm 0.007$ & $0.309 \pm 0.008$ & $0.681 \pm 0.042$ & $0.177 \pm 0.024$ & $0.210 \pm 0.007$ & $0.248 \pm 0.051$ & $0.411 \pm 0.017$ \\
\hline $\begin{array}{l}\text { Indirectly } \\
\text { polluted }\end{array}$ & $0.190 \pm 0.009$ & $0.173 \pm 0.003$ & $0.335 \pm 0.020$ & $0.587 \pm 0.053$ & $0.139 \pm 0.014$ & $0.146 \pm 0.009$ & $0.253 \pm 0.036$ & $0.458 \pm 0.025$ \\
\hline $\begin{array}{c}\text { Non- } \\
\text { polluted }\end{array}$ & $0.216 \pm 0.029$ & $0.148 \pm 0.006$ & $0.465 \pm .0 .116$ & $0.478 \pm 0.111$ & $0.181 \pm 0.024$ & $0.152 \pm 0.008$ & $0.357 \pm 0.095$ & $0.428 \pm 0.014$ \\
\hline
\end{tabular}

\begin{tabular}{|c|c|c|c|c|c|c|c|c|}
\hline \multirow{3}{*}{ Location } & \multicolumn{8}{|c|}{ Fruity vegetables } \\
\hline & \multicolumn{4}{|c|}{ Bottle gourd } & \multicolumn{4}{|c|}{ Pumpkin } \\
\hline & Mn & $\mathrm{Fe}$ & $\mathrm{Cu}$ & $\mathbf{Z n}$ & Mn & $\mathbf{F e}$ & $\mathbf{C u}$ & $\mathbf{Z n}$ \\
\hline $\begin{array}{l}\text { Directly } \\
\text { polluted }\end{array}$ & $0.075 \pm 0.008$ & $0.095 \pm 0.008$ & $0.244 \pm 0.053$ & $0.461 \pm 0.028$ & $0.087 \pm 0.006$ & $0.068 \pm 0.003$ & $0.228 \pm 0.031$ & $0.412 \pm 0.040$ \\
\hline $\begin{array}{l}\text { Indirectly } \\
\text { polluted }\end{array}$ & $0.080 \pm 0.10$ & $0.051 \pm 0.005$ & $0.337 \pm 0.058$ & $0.345 \pm 0.005$ & $0.091 \pm 0.009$ & $0.062 \pm 0.011$ & $0.241 \pm 0.048$ & $0.417 \pm 0.003$ \\
\hline $\begin{array}{c}\text { Non- } \\
\text { polluted }\end{array}$ & $0.078 \pm 0.007$ & $0.045 \pm 0.006$ & $0.295 \pm 0.027$ & $0.388 \pm 10.057$ & $0.083 \pm 0.010$ & $0.053 \pm 0.008$ & $0.363 \pm 0.109$ & $0.442 \pm 0.015$ \\
\hline
\end{tabular}


High concentration of these metals in polluted area's vegetables might be due to high contents of metals in the soil as caused by irrigation with metal contaminated water released from different kinds of industries. The river Turag is highly polluted by industrial effluents, sewage sludge, municipal waste water, and urban pollution. Comparatively low concentration of metal ions in vegetables from indirectly polluted area (Zorun) might be due to the pattern of contamination, where pond and canals' contaminated water submered the adjacent cultivable land during rainy season after that the farmers grew their vegetables in winter. However, the higher concentrations of $\mathrm{Cu}, \mathrm{Fe}, \mathrm{Mn}$ and $\mathrm{Zn}$ in the polluted (either directly or indirectly) area indicates that industrial activities, such as textile, paint, battery, milling, and chemical industries contaminate or introduce heavy metals into the soil.

\section{Conclusion}

Based on the information generated from the study, it may be concluded that industrial effluents and urban pollution associated with sewage sludge and municipal wastes within the vicinity of Turag river have increased the levels of $\mathrm{Mn}, \mathrm{Fe}, \mathrm{Cu}$, and $\mathrm{Zn}$ in the water of Turag river. As a result, vegetable crops grown here with irrigation water from Turag river contain higher concentrations of these elements as compared to those grown in non-polluted area of BARI.

\section{References}

Ahmad, J. A. and M. A. Goni. 2009. Heavy metal contamination in water, soil, and vegetables of the industrial areas in Dhaka, Bangladesh. Environ Monit Assess. DOI 10.1007/1-11.

Alam, M.G.M., E.T. Snow and A. Tanaka. 2003. Arsenic and heavy metal contamination of vegetables grown in Samta village, Bangladesh. The Science of the Total Environment 308: 83-96.

Alloway, B.J. 1990. Heavy Metal in Soils. ed. Blackie and Son Ltd., Glasgow, England., Pp: 177-196.

Arora, M., B. Kiran, A. Rani, S. Rani, B. Kaur and M. Mittal. 2008. Heavy metal accumulation in vegetables irrigated with water from different sources. Food Chemistry 111: 811-815. doi:10.1016/ j.foodchem.2008.04.049.

Awashthi, S. K. 2000. Prevention of Food Adulteration Act No. 37 of 1954. Central and State rules as amended for 1999 (3rd ed.). New Delhi: Ashoka Law House.

Bigdeli, M. and M. Seilsepour. 2008. Investigation of metals accumulation in some vegetables irrigated with waste water in Shahre-Rey-Iron and Toxicological implication. American-Eurasian J. Agric \& Environ. Sci. 4(1):86-92.

Chamon, A. S., M.H. Gerzabek, M.N. Mondal, S. M. Ullah, M. Rahman and W. H. Blum. 2011. Influence of cereal varieties and site conditions on heavy metal 
accumulation in cereal crops on polluted soils of Bangladesh. Communications in Soil Science and Plant Analysis 36(7): 889-906.

Codex Alimentarius Commission (FAO/WHO). 2001. Food additives and contaminantsJoint FAO/WHO Food Standards Programme. ALINORM 01/12A, Pp.1-289.

Dowdy, R.H. and W.E. Larson. 1975. The availability of sludge borne metals to various vegetable crops. Journal of Environmental Quality. 4: 278-282.

Farooq, M., R. K. Hans, P. N. Viswanathan and JP. C. oshi. 1999. Health hazard from dry river bed agriculture. Bull. Environ. Contam. Toxicol. 62:555-562.

Guttormsen, G, B.R. Singh and A.S. Jeng. 1995. Cadmium concentration in vegetable crops grown in a sandy soil as affected by Cd levels in fertilizer and soil. pH Fert. Res. 41: 27-32.

Hussain, S. I., A. Ghafoor, S. Ahmad, G. Murtaza and M. Sabir. 2006. Irrigation of crops with raw sewage: Hazard Assessment of effluent, soil and vegetables. Pak. J. Agri. Sci. 43(3-4):97-102.

Kabata-Pendias, A., \& Pendias, H. 1992. Trace elements in soil and plants (2nd ed., p. 365). Boca Raton: CRC.

Kashif, S. R., M. Akram, M. Yaseen and S. Ali. 2009. Studies on heavy metals status and their uptake by vegetables in adjoining areas of Hudiara drain in Lahore. Soil \& Environ. 28(1): 7-12.

Khan, S., Q. Cao, Y. M. Zheng, Y. Z. Huang and Y. G. Zhu. 2008. Health risks of heavy metals in contaminated soils and food crops irrigated with wastewater in Beijing, China. Environmental Pollution. 152: 686-692. doi:10.1016/j.envpol.2007.06.056.

Liu, W. H., J. Z. Zhao, Z. Y. Ouyang, L. Soderlund and G. H. Liu. 2005. Impacts of sewage irrigation on heavy metals distribution and contamination. Environment International, 31, 805-812. doi:10.1016/j.envint.2005.05.042.

Liu, W., X. Li, H. H. Sr. Li and Y. W. Wang. 2006. Heavy metal accumulation of edible vegetables cultivated in agricultural soil in the Suburb of Zhengzhou City, People's Republic of China. Bulletin of Environmental Environmental Contamination and Toxicology 76: 163-170. doi:10.1007/s00128-006-0981-3.

Mapanda, F., E. N. Mangwayana, J. Nyamangara and K. E. Giller. 2005. The effect of long-term irrigation using wastewater on heavy metal contents of soils under vegetables in Harare, Zimbabwe. Agriculture Ecosystems \& Environment 107: 151165. doi:10.1016/j.agee.2004.11.005.

Mingorance, M. D., B. Valdes and S. Oliva Rossini. 2007. Strategies of heavy metal uptake by plants growing under industrial emissions. Environment International. 33(4): 514-520. doi:10.1016/j.envint.2007.01.005.

Mico, C., M. Peris, J. Sanchez and L. Recatala. 2006. Heavy metal content of agricultural soils in a Mediterranean semiarid area: the Segura river valley (Alicante, Spain). Spanish Journal of Agricultural Research 4(4):363-372.

Muchuweti, M., J. W. Birkett, E. Chinyanga, R. Zvauya, M. D. Scrimshaw and J. Lester. 2006. Heavy metal content of vegetables irrigated with mixture of wastewater and 
sewage sludge in Zimbabwe: Implications for human health. Agriculture Ecosystems \& Environment 112, 41-48. doi:10.1016/j.agee.2005.04.028.

NEPA. 1995. National Environmental Protection Agency of China, GB 15618.

Nuruzzaman, M., M. H. Gerzabek and S. M. Ullah. 1995. Studies on Heavy Metal and Microbiological Pollution of Soils, Sediments and Water Systems in and Around Dhaka City; Bericht an die O" sterr. Akademie der Wissenschaften, Austrian Research Centers Seibersdorf (O“ FZS): Vienna, Austria, 5-20.

Prabu, P. C. 2009. Impact of heavy metal contamination of akaki River of ethiopia on soil and metal toxicity on Cultivated vegetable crops. Electronic Journal of Environmental, Agricultural and food Chemistry 8(9): 818-827.

SEPA. 2005. The limits of pollutants in food. China: State Environmental Protection Administration GB2762-2005.

Sharma, R. K., Agrawal, M., \& Marshall, F. 2007. Heavy metal contamination of soil and vegetables in suburban areas of Varanasi, India. Ecotoxicology and Environmental Safety 66: 258-266. doi:10.1016/j.ecoenv.2005.11.007.

Ward, N.I. 1995. In: Environmental analytical chemistry-Trace elements. (Eds.F.W. Fifield, and P.J. Haines.), Blackie Academic and Professional, UK, Pp.320-328. 